\title{
Wind-induced variability in larval retention in a coral reef system: a biophysical modelling study in the South-West Lagoon of New Caledonia
}

\author{
Marion Cuif ${ }^{a}, b, c, *$, David Michael Kaplan ${ }^{a}$, Jérôme Lefèvre ${ }^{d}$, Vincent Martin Faure ${ }^{e}$, Matthieu Caillaud ${ }^{\mathrm{f}}$, \\ Philippe Verley $^{\mathrm{g}}$, Laurent Vigliola ${ }^{\mathrm{b}}$, Christophe Lett $^{\mathrm{c}}$
}

\begin{abstract}
a Institut de Recherche pour le Développement (IRD), UMR 212 EME, Centre de Recherche Halieutique Méditerranéenne et Tropicale, BP 17134203 Sète cedex, France

${ }^{\mathrm{b}}$ Institut de Recherche pour le Développement (IRD), Laboratoire d'Excellence LABEX Corail, UR COREUS, BP A5 98848 Nouméa cedex, New Caledonia

c Institut de Recherche pour le Développement (IRD), UMI 209 UPMC UMMISCO, Centre de Recherche Halieutique Méditerranéenne et Tropicale, BP 17134203 Sète cedex, France

d Institut de Recherche pour le Développement (IRD), LEGOS/MIO, BP A5 98848 Nouméa cedex, New Caledonia e Aix-Marseille University, Mediterranean Institute of Oceanography (MIO), 13288, Marseille, Cedex 9, France;Université du Sud Toulon-Var, 83957, La Garde Cedex, France CNRS-INSU/IRD UM 110

${ }^{f}$ DYNECO/PHYSED IFREMER, Centre de Bretagne Technopôle de Brest-Iroise, BP 70, 29280 Plouzané, France

9 Institut de Recherche pour le Développement (IRD), UMR 212 EME, Marine Research Institute and Oceanography Department, University of Cape Town, Private Bag X3, Rondebosch, Cape Town 7701, South Africa
\end{abstract}

*: Corresponding author : Marion Cuif, tel.: +33499573252 ; email address : marion.cuif@ird.fr

\begin{abstract}
:
In the present work, a biophysical dispersal model is used to understand the role of the physical environment in determining reef fish larval dispersal patterns in the South-West Lagoon of New Caledonia. We focus on a reef fish species, the humbug damselfish Dascyllus aruanus, to investigate seasonal variability of simulated larval retention at the scale of a reef patch and at the scale of the lagoon, and to explore links between larval retention and wind variability. The model shows that retention exhibits considerable temporal variability and periodically reaches values much larger than anticipated. Non-zero larval settlement occurs over a large part of the lagoon. Nevertheless, settlement values decrease quickly away from the natal reef and mean dispersal distances are of order 25-35 km. Cross-correlation analyses indicate that weather conditions characterized by strong south east trade winds lead to low retention rates at both local (reef) and regional (lagoon) scales. By contrast, subtropical weather conditions characterized by weak winds result in high retention rates. These results suggest that largescale weather regimes can be used as proxies for larval retention of the humbug damselfish in the South-West Lagoon of New Caledonia. Nevertheless, relatively small mean dispersal distances suggest that meta-population dynamics occur on relatively small spatial scales.
\end{abstract}

\section{Highlights}

- We develop a biophysical, individual-based model for larvae of Dascyllus aruanus. Larval retention at natal reef and lagoon scales is highly variable over time. Large-scale weather regimes are good proxies for retention rates. Mean dispersal distances are of order $25-35 \mathrm{~km}$.

Keywords : Biophysical model ; Larval dispersal ; Wind-driven transport ; Dascyllus aruanus ; Precompetency ; Homing ; New Caledonia 


\section{Introduction}

The fragmentation of marine coastal habitats results in a geographical separation of local populations. Links among local populations are possible via the movement of individuals. When these connections are strong enough to have a measurable impact on local populations' growth rates, these populations constitute a metapopulation (Sale et al. 2006) and the exchanges between them are referred to as demographic connectivity (Cowen et al. 2007).

Knowledge of demographic connectivity is required to understand metapopulation dynamics and the persistence and resilience of marine populations to anthropogenic pressures (Bernhardt and Leslie 2013), particularly in the context of implementing networks of marine protected areas (Sale et al. 2005). While progress has been made with older life stages, the larval dispersal component of connectivity has long been viewed as a black-box due to the many difficulties associated with directly observing a multitude of small individuals in a marine environment. In the past decade, advances in biophysical modelling (Miller 2007) and empirical techniques for connectivity assessment (e.g. genetic parentage analysis using DNA microsatellites and otolith transgenerational tagging) have permitted detailed investigation of early life dispersal (reviewed in Levin 2006, Cowen and Sponaugle 2009, Leis et al. 2011, Kool et al. 2013), especially in coral reef systems (Jones et al. 2009). Although numerous marine species have pelagic larval durations that may last several weeks, Cowen et al. (2000) showed more than ten years ago that the spatial scales of larval dispersal were not as large as anticipated (only 10 to $100 \mathrm{~km}$ vs. several hundreds of $\mathrm{km}$ as was previously thought). This result suggested that larval local retention (i.e. the ratio of the number of larvae that settled back to their natal population to the total number of larvae released there, Botsford et al. 2009) could be important for the functioning and structure of marine populations. Since then, the idea of small scale demographic connectivity ensured by larval retention has been supported by modelling studies e.g. in the Great Barrier Reef in Australia (James et al. 2002), 
the Caribbean (Cowen et al. 2006, Chérubin et al. 2011), Hawaii (Christie et al. 2010) and the Indo-Pacific Ocean (Treml et al. 2012). Field observations also reported high levels of selfrecruitment (i.e. the ratio of the number of larvae that settled back to their natal population to the total number of larvae that settled there, Botsford et al. 2009) e.g. for reef fish species in Papua New Guinea (Almany et al. 2007, Planes et al. 2009, Saenz-Agudelo et al. 2012, Berumen et al. 2012), the Caribbean (Hogan et al. 2012) and the Great Barrier Reef (Harrison et al. 2012, van der Meer et al. 2012).

The present challenge of larval dispersal research is to find out if this relatively "closed" population dynamics is the rule or the exception, and to understand its causes: does it result from local oceanography, larval life history traits, larval behavior, or a combination of these biotic and abiotic drivers? Local oceanography (currents, water residence time) has been shown to be of great importance for explaining relatively closed population dynamics (Paris and Cowen 2004, Treml et al. 2012). Among life history traits, the length of the larval precompetency period, i.e. the period of time in which larvae may not settle (Jackson and Strathmann 1981), has been shown to be a key driver for local retention within the natal population (Black and Moran 1991, Paris and Cowen 2004, Treml 2012). Whereas the precompetency period of reef-building coral larvae is relatively short (between 2 and 5 days, Heyward and Negri 2010), the precompetency period can reach several weeks for other reef species (Staaterman et al. 2012, Butler et al. 2011, Soria et al. 2012). Concerning larval behavior, several studies demonstrate that fish larvae have sensory capabilities coupled with strong swimming capabilities (Leis 2010) that facilitate local retention through homing. For instance, larvae are capable of olfactory discrimination and prefer the odor of their home reef (Gerlach et al. 2007). Acoustic (e.g. Radford et al. 2011) and sun compass mechanisms (Mouristen et al. 2013) have also been suggested to allow pelagic larvae to locate their natal reef. Modelling studies show that early active larval movement associated with orientation 
behavior is a mechanism for self-recruitment (James et al. 2002, Paris et al. 2005, Staaterman et al. 2012).

In this study we investigate the roles of local meteo-oceanography, precompetency period and homing behavior in determining reef fish larval retention in the South-West Lagoon of New Caledonia (SWL). The oceanography of the SWL has been particularly well studied over the last forty years through in-situ measurements and numerical models that provide insights on sediment transport and biogeochemical dynamics in the lagoon (Jarrige et al. 1975, Douillet 1998, Faure et al. 2010, Ouillon et al. 2010, Fuchs et al. 2012). Previous studies using Lagrangian tracers show that the SWL is well mixed by the joined action of tide currents, winds and swell which results in a rather low average water residence time of 11 days (defined as the time needed for a water particle to leave the lagoon) (Jouon et al. 2006, Ouillon et al. 2010). If we assume, as a first approximation, that larvae of marine species are passive entities during their precompetency period, and are therefore advected like water parcels, the short water residence time found in the SWL has enormous consequences for larval retention: species with a larval precompetency period longer than 11 days will be mostly flushed out of the lagoon.

In this study we focus on a coral reef damselfish, Dascyllus aruanus, a species that has precisely a precompetency period of $\sim 11$ days (see Material and methods 2.3 ). We use a three-dimensional biophysical model to investigate larval retention of Dascyllus aruanus and its seasonal variability inside the SWL. We first describe the study species and region focusing on the oceanographic context. The biophysical model is then described and used to assess larval retention at two different spatial scales: SWL scale ("natal lagoon retention") and local patch reef scale ("natal reef retention"). We define (1) "natal lagoon retention" and (2) "natal reef retention" as the ratio of the number of larvae released at the natal reef that settled (1) on any of the settlement reefs including the natal reef or (2) only on the natal reef, to the 
103

104

105

106

107

108

109

total number of larvae released at the natal reef . Larval retention was simulated under two opposite hypotheses regarding homing behavior: a strict-homing hypothesis and a no-homing hypothesis. Finally, to stress out the role of the local meteo-oceanography on larval retention, our results are linked to the synoptic-scale variability of the low-level circulation in New Caledonia that we can describe through the so-called weather regimes (Lefèvre et al. 2010). A sensitivity study is conducted using a longer (3 weeks) precompetency period and different larval release depths. 


\section{Material and methods}

\subsection{Study area}

New Caledonia $\left(19-23^{\circ} \mathrm{S}, 163-168^{\circ} \mathrm{E}\right)$ is an island located in the South West Tropical

Pacific $1500 \mathrm{~km}$ east of Australia. The New Caledonia lagoon is surrounded by a barrier reef of exceptional size (1600 km in length, the second longest double barrier reef in the world, after the Great Barrier Reef) and is listed as a UNESCO World Heritage Site since 2008. The work presented here focuses on the South-West Lagoon of New Caledonia (SWL) which surrounds Nouméa, the island's main city (Figure 1). A network of 13 Marine Protected Areas (MPAs) has been established in this area to mitigate the increasing anthropogenic pressure on the lagoon. The SWL covers an area of about $2000 \mathrm{~km}^{2}$ delimited by the coast on the eastern side and the barrier reef on the western side, extending from the Mato pass in the south to the Ouaraï pass in the north. Depth averages $20 \mathrm{~m}$ and varies from less than $1 \mathrm{~m}$ around islets to $60 \mathrm{~m}$ inside canyons. The lagoon ranges in width from $5 \mathrm{~km}$ (northern limit) to $40 \mathrm{~km}$ (southern limit) with a length along the north-west/south-east axis of about $100 \mathrm{~km}$, and is connected with the Pacific Ocean by several deep passes.

\subsection{Local meteo-oceanography in summertime}

The two main forces driving circulation in the SWL are tides and winds (Douillet 1998).

Wind-induced current velocities are approximately one order of magnitude higher than velocities generated by tides (Ouillon et al. 2010). Austral summer (from October to March) is dominated by southeasterly trade winds blowing from $60^{\circ}$ to $160^{\circ}$ at speeds averaging $8 \mathrm{~m}$ $\mathrm{s}^{-1}$ (Pesin et al. 1995). Recently, Lefèvre et al. (2010) identified four weather regimes occurring in New Caledonia during austral summer through an objective classification applied to remote sensed winds for nine seasons from 1999 to 2008 (Table 1). Three of these weather regimes (regimes 1, 3 and 4) exhibit low-level circulation dominated by SE trade winds. 
Regime 1 captures a strong, near steady and alongshore trade wind flow, averaging $8 \mathrm{~m} \mathrm{~s}^{-1}$ and is referred to here as "Strong SE Trade-wind". This regime is the most frequent, accounting for slightly less than a third of the austral summer days. Long spells of "Strong SE Trade-wind" (regime 1) are more favorable to the flushing of the lagoon by driving a general north-west drift. The SWL is thus mainly fed with oceanic waters at its southern end, through the different passes of the barrier reef as described in Jouon et al. (2006). This regime promote the formation of upwelling events along the barrier reef (Marchesiello et al, 2010) and local wind acceleration in SWL due to flow splitting by the mountainous island (Lefèvre et al., 2010). The regional circulation in regime 4, called "Subtropical SE wind", also shows a near steady alongshore SE direction, but with weaker winds $\left(5.2 \mathrm{~m} \mathrm{~s}^{-1}\right.$ in average) associated with strong subtropical westerlies south of the island. Occurring for $27 \%$ of the days in Lefèvre et al.'s (2010) analysis, this regime is more frequent in early summer (NovemberDecember). Regime 3, called "Tropical SE wind", accounts for $22 \%$ of the days, occurs more frequently during the warm and wet period from January to March, and produces average winds of $5.2 \mathrm{~m} \mathrm{~s}^{-1}$. The fourth regime, regime 2, called "Weak Easterly Circulation", exhibits a weak easterly airflow circulation (below $2 \mathrm{~m} \mathrm{~s}^{-1}$ ) and the largest variability in wind direction. It is also the most transient and least robust regime, accounting for less than $8 \%$ of the days.

\subsection{Study species}

This study is part of a larger program focusing on the population connectivity of the Humbug damselfish (Pomacentridae), Dascyllus aruanus, in the SWL of New Caledonia. Here, we therefore use the larval life history traits of this species as the basis for our exploration of larval dispersal patterns in the SWL. D. aruanus is an obligate coral-dwelling Pomacentridae, found exclusively in lagoon habitats (Allen 1991), where it lives in well-mixed waters among branching coral colonies in spatially discrete groups of 2 to 80 individuals (Sale 1972, 
Holbrook et al. 2000, Cole 2002). Coral colonies provide protection from predators and substrate for laying benthic eggs (Coates 1980, Mizushima et al. 2000). D. aruanus adults are sedentary benthic spawners that breed on a lunar cycle throughout the year (Pillai et al. 1985). Spawning peaks in summer, during which time each female can spawn several times at one week (personal observation) to 2 months (Mizushima et al. 2000) intervals. Eggs remain in benthic nests for 3 days after which hatchlings are released into the plankton where they disperse on average 3 weeks (mean planktonic larval duration -PLD- Thresher et al. 1989, Juncker et al. 2007, Soeparno et al. 2012) prior to settling on adult reef habitats. Newly hatched larvae have well developed sensorial abilities (Leis 2010) and pomacentrids larvae are able to swim actively against currents during the second half of their pelagic larval phase (Fisher 2005). Furthermore, field evidence indicates that late-stage larvae of coral reef fish can detect the presence of a reef at a range of at least $1 \mathrm{~km}$ (Leis et al. 1996). Thus the sensorial and swimming abilities which allow the orientation of competent larvae to suitable recruitment habitat (Sweatman 1983, Holbrook et al. 2000) may be present in D. aruanus larvae as early as the age of 11 days (i.e. half of mean PLD).

\subsection{Biophysical model}

Larval dispersal was simulated with a biophysical model using version 3.0 of the Lagrangian tool Ichthyop (Lett et al. 2008). Ichthyop is a three-dimensional (3D) particle-tracking model designed to study the effects of physical and biological factors on the transport and settlement of ichthyoplankton. The biophysical model is based on an offline forcing of an individualbased model (IBM) by a 3D hydrodynamic model. The hydrodynamic model used here is the high-resolution 3D Model for Applications at Regional Scales (MARS3D, Lazure and Dumas 2008). MARS3D provides 3D dynamic fields of current velocities which result from the combined actions of wind and tidal forcing. Several configurations of this model have been developed and validated in the SWL (Douillet 1998, Douillet et al. 2001, Ouillon et al. 2010). 
The configuration of MARS3D used in this study covers the SWL from $22.06^{\circ}$ to $22.52^{\circ} \mathrm{S}$ and from $165.98^{\circ}$ to $166.79^{\circ} \mathrm{E}$. The model grid has a horizontal resolution of $500 \mathrm{~m}$ and thirty terrain following generalized sigma levels in the vertical dimension. This configuration is forced by realistic hourly winds at $4 \mathrm{~km}$ resolution obtained from the mesoscale Weather Research and Forecasting model (WRF) (Lefèvre et al. 2010). Simulated surface wind speeds and directions are very close to observations (Indice of Agreement IOA of 0.9 and RMSE < standard deviation of observations for both speed and direction, Appendix A, Table A.1). Realistic wind forcing corresponds to the years 2003-2004. This period is neutral regarding ENSO phases. Tides are included in MARS3D through a lateral forcing using the Oregon State University TPXO.6 tides solution (Egbert et al. 1994) for 8 tidal constituents. The TPXO tides solution is refined further within ADCIRC (ADvanced CIRCulation model, Luettich and Westerink 1992), by using an unstructured and very fine resolution mesh (from 500 to $25 \mathrm{~m}$ in the SWL, Lefèvre, pers. comm.).

Our larval transport IBM uses MARS3D model results covering the reproductive period of $D$. aruanus in New Caledonia i.e. from mid-September to late March. Outputs of MARS3D simulations were stored every 12 minutes as this time step is sufficient to account for the effects of tides. In the IBM, larvae are characterized by their latitude $\left({ }^{\circ} \mathrm{S}\right)$, longitude $\left({ }^{\circ} \mathrm{E}\right)$ and depth $(m)$. Locations of individuals are updated every five minutes in three dimensions using the velocity fields stored from MARS3D interpolated in space and time via a forward-Euler integration scheme.

\subsection{Simulations}

In order to study the effect of wind regime on larval retention, we examined dispersal from a $\sim 500 \mathrm{~m}$ diameter patch reef located at the center of the SWL (called natal reef hereafter) where water residence time is close to the average of 11 days (Ouillon et al. 2010). Location 
and extent of the natal reef and settlement areas in the SWL were defined as polygons based on GIS habitat maps provided by the atlas of coral reefs in New Caledonia (Andrefouët et al. 2004). Since D. aruanus is ubiquitous in the SWL all reefs shallower than $20 \mathrm{~m}$ were considered as potential settlement habitats in the model. Hatching events (representing a release of 500 virtual larvae each) were simulated over the natal reef every three hours over austral summer from mid-September 2003 to late March 2004 (i.e. 1320 simulations). For each release on the natal reef, larvae were randomly distributed throughout the water column from 0 to $20 \mathrm{~m}$ depth. Larvae from each hatching event were followed for up to 30 days (the largest value of PLD for D. aruanus). We considered that larvae were initially transported passively by ocean currents during an 11-day precompetency period and that they became active afterwards with sensory and swimming capabilities that allowed them to detect and approach a settlement area. To do so, a non-explicit swimming behavior during the competency period was included by assuming that larvae could actively settle once at a given distance from a settlement reef. This distance was defined as $1 \mathrm{~km}$ (Leis et al. 1996). Any virtual larva located less than $1 \mathrm{~km}$ away from a settlement reef at any time between the end of the precompetency period and 30 days was then considered to have successfully settled.

Simulations were run under two alternative hypotheses about natal homing. Under the first hypothesis, settlement was supposed to be driven by strict natal homing: settlement was only allowed at the natal reef, i.e. competent larvae were only able to settle on the natal reef. We will refer to this hypothesis as the "strict-homing hypothesis". Under the second hypothesis, settlement of competent larvae was allowed on the natal reef and in any other part of the SWL where suitable habitat for D. aruanus was available. We will refer to this hypothesis as the "no-homing hypothesis". A longer precompetency period of three weeks (21 days) was also tested. A sensitivity analysis to the larval release depth was also conducted using simulations run for a precompetency period of 11 days for both hypotheses regarding natal homing. As 
larvae are characterized by their latitude $\left({ }^{\circ} \mathrm{S}\right)$, longitude $\left({ }^{\circ} \mathrm{E}\right)$ and depth $(\mathrm{m})$ at each time step, it is possible to know the release depth of each recruited larvae at the end of the simulation. Five release depth intervals were tested from 0 to $20 \mathrm{~m}$. All post-processing computations were done using $\mathrm{R}$ version 2.14.1.

\subsection{Lagoon vs. reef retention}

Simulation outputs were used to calculate larval retention at two different spatial scales.

Larval retention was first computed for each simulation at the SWL scale. This retention, hereafter called "natal lagoon retention" (NLR), is defined as the ratio of the number of larvae released at the natal reef that settled on any of the settlement reefs to the total number of larvae released at the natal reef. Larval retention was also computed for each hatching event at the natal reef scale. This local retention, hereafter referred to as "natal reef retention" (NRR), is defined as the ratio of the number of larvae released at the natal reef that settled back to that site to the total number of larvae released at the natal reef. Three retention time series extending from mid-September 2003 to early March 2004 were obtained: NLR under the nohoming hypothesis; NRR under the no-homing hypothesis; NRR under the strict-homing hypothesis. Note that under the strict-homing hypothesis NLR equals NRR.

\subsection{Cross-correlations}

To study the link between wind conditions and simulated $D$. aruanus larval retention, we calculated cross-correlations between wind and retention time series with a maximum lag of 30 days. We extracted hourly meridional and zonal wind components from the WRF model at the closest grid point to the natal reef and converted them into an along-shelf (V-component) and cross-shelf (U-component) coordinate system, rotated $60^{\circ}$ anti-clockwise from true north, with $\mathrm{V}$ positive towards the north-west $\left(300^{\circ}\right)$ and $\mathrm{U}$ positive onshore towards $30^{\circ}$. Time series of daily probability of occurrence of the four weather regimes defined by Lefèvre et al. 
(2010) were also used in a cross-correlation analysis with simulated retention time series. We used the Spearman rank-order correlation coefficient (hereafter Spear-R) because the simulated retention values were not normally distributed. Given that autocorrelation of time series increases the risk to consider that correlations between series are significant when they are not, we accounted for autocorrelation of all time series explicitly in judging the significance of correlations by adjusting the degrees of freedom following Pyper and Peterman (1998) and Botsford and Paulsen (2000). Auto-correlation timescales of order 2-8 days, depending on the simulation and time series examined, were identified and the effective degrees of freedom were corrected accordingly. This correction reduced the effective degrees of freedom and consequently substantially increased the value of correlation required for a significant result. All reported correlation coefficients are significantly different from zero at the $95 \%$ confidence level.

\subsection{Larval settlement maps}

Larval settlement maps were plotted at the SWL scale from the simulations with the nohoming hypothesis. For each hatching event, the spatial distribution of settlers was computed for square grid cells of $0.01^{\circ}$ spatial resolution. The proportional number of settlers (relative to the total number of released larvae $=500$ ) in each grid cell was then averaged over all hatching events, as well as over two extreme decompositions of the simulation period: (1) hatching events whose precompetency period consisted of at least $75 \%$ weather regime 1 (Strong SE Trade-wind, Table 1) and (2) hatching events whose precompetency period consisted of at least $75 \%$ weather regime 4 (Subtropical SE wind, Table 1). The centers of mass of settlement maps were then calculated as the weighted (by settlement) spatial average over grid cells. To enhance visibility, some results were converted to a logarithmic scale by calculating $\log _{10}\left(N_{i}+1\right)$ where $N_{i}$ is the total number of larvae, over all simulations, settling in grid cell $i$. 


\section{Results}

\subsection{Time series}

The retention time series exhibit considerable temporal variability for both precompetency periods (Figure $2 \mathrm{a}$ and $2 \mathrm{~b}$ ). For an 11-day precompetency period, natal lagoon retention (NLR) ranges from $0 \%$ to $100 \%$ with a mean of $56.7 \%$ ( $\pm 26.4 \%$ Std. Dev.). Natal Reef Retention (NRR) ranges from $0 \%$ to $42.6 \%$ with a mean of $6.7 \%( \pm 8.2 \%$ Std. Dev.) under the strict-homing hypothesis. Under the no-homing hypothesis, NRR is considerably smaller, ranging from $0 \%$ to $23.0 \%$ with a mean of $1.4 \%$ ( $\pm 2.3 \%$ Std. Dev.). The three simulated retention time series are highly positively correlated (Spear-R $0.63,0.82$, and 0.73 , for the NLR and NRR when no homing, NLR and NRR when strict homing, and NRR when no homing and NRR when strict homing time series, respectively). At both spatial scales (natal reef and natal lagoon) and under both hypotheses (strict and no homing), mean retention decreases as the precompetency period increases. For a 21-day precompetency period, NLR ranges from $0 \%$ to $86.4 \%$ with a mean of $32.9 \%$ ( $\pm 20.9 \%$ Std. Dev.). NRR ranges from $0 \%$ to $18.8 \%$ with a mean of $1.9 \%$ ( $\pm 3.0 \%$ Std. Dev.) under the strict-homing hypothesis. Under the no-homing hypothesis, it ranges from $0 \%$ to $4.0 \%$ with a mean of $0.3 \%( \pm 0.5 \%$ Std. Dev.).

Wind conditions simulated by WRF model over austral summer 2003-2004 show two predominant states (Figure 2c) representing each about a third of the time series. Periods corresponding to trade winds with wind speed $>8 \mathrm{~m} \mathrm{~s}^{-1}$ and steady direction (mean $=110^{\circ} \mathrm{N}$ \pm 23 Std. Dev.) alternate with periods with weak wind speed $\left(<5 \mathrm{~m} \mathrm{~s}^{-1}\right)$ and variable direction (mean $=160^{\circ} \mathrm{N} \pm 88$ Std. Dev.). During trade wind episodes the along-shore wind component (V) is high towards North-West (mean $=8.6 \mathrm{~m} \mathrm{~s}^{-1} \pm 2.0 \mathrm{Std}$. Dev.) and the cross-shelf wind component $(\mathrm{U})$ is oriented offshore (mean $=-1.5 \mathrm{~m} \mathrm{~s}^{-1} \pm 2.4 \mathrm{Std}$. Dev.), whereas weak and 
variable wind episodes are characterized by a lower V (mean $=1.2 \mathrm{~m} \mathrm{~s}^{-1} \pm 2.3 \mathrm{Std}$. Dev.) and higher $\mathrm{U}$ component towards the coast (mean $=0.1 \mathrm{~m} \mathrm{~s}^{-1} \pm 2.3 \mathrm{Std}$. Dev.) (Figures $2 \mathrm{c}$ and $2 \mathrm{~d}$ ). Consistent with these conditions, wind regimes 1 (Strong SE Trade-wind) and 4 (Subtropical SE wind) are predominant during the study period (Figure 2e), occurring $35 \%$ and $43 \%$ of the study period, respectively. Regimes 2 (weak easterly circulation) and 3 (tropical SE wind) winds represent $8 \%$ and $13 \%$ of the study period, respectively.

\subsection{Cross-correlations}

\section{Natal lagoon retention (NLR)}

For an 11-day precompetency period, the time series of NLR shows significant negative cross-correlations with the along-shore component of wind (Figure 3a) between days 2 and 9 after release, with an absolute maximum correlation coefficient of 0.3 occurring at a lag of 5 days. For a 21-day precompetency period, correlations are consistently negative at about -0.2 for lags of 3-20 days, albeit only marginally significant at lags of 12-13 days and 18-19 days (correlation coefficient of - -0.3) (Figure 3b). Cross-correlations with the cross-shelf component are not significant. For both precompetency period lengths, NLR is negatively correlated with the probability of weather regime 1 (Figure 4a and 4b) between days 2 and 5 after release with absolute maximum correlation coefficients of 0.4 . NLR is not significantly correlated to regime 4, but correlation coefficients are generally positive (Figure 4c and 4d) for both precompetency period lengths. Cross-correlations with regimes 2 and 3 are not significant.

\section{Natal reef retention (NRR)}

Time series of NRR under the strict-homing hypothesis show significant negative crosscorrelations with the along-shore component of wind for both precompetency period lengths (Figures 3a and 3b). Significant correlations occur between days 3 and 10 and between days 
5 and 13 after release for precompetency period lengths of 11 and 21 days respectively, with absolute maximum correlation coefficients of 0.3 for both precompetency period lengths (Figures $3 \mathrm{a}$ and $3 \mathrm{~b}$ ). Under no-homing hypotheses NRR is not significantly correlated to along-shore winds for a precompetency of 11 days, but correlation coefficients are generally negative at the beginning of the precompetency period (Figure 3a). The time series of NRR under the no-homing hypothesis shows significant negative cross-correlations with alongshore winds between 5 and 7 days for a precompetency of 21 days (Figure 3b), with an absolute maximum correlation coefficient of 0.2. Cross-correlations with cross-shelf winds are not significant.

For an 11-day precompetency period, NRR under the strict-homing hypothesis is significantly and negatively correlated to regime 1 at day 4 with an absolute maximum correlation coefficient of 0.4 (Figure 4a) and NRR under the no-homing hypothesis is not significantly correlated to weather regime 1 at the beginning of the PLD, but the correlation coefficients are consistently negative (Figure 4a). For an 11-day precompetency period, NRR is significantly and positively correlated with regime 1 between days 16 and 24 (no-homing hypothesis) and between days 17 and 19 (strict-homing hypothesis) with maximum correlation coefficients of 0.4 (Figure 4a). For a 21-day precompetency period with the nohoming hypothesis, NRR is significantly and negatively correlated with regime 1 between days 3 and 6, with an absolute maximum correlation coefficient of 0.4 (Figure 4b). For a 21day precompetency period with the strict-homing hypothesis, NRR is significantly and positively correlated with regime 1 between days 21 and 24, with a maximum correlation coefficient of 0.4 (Figure $4 b$ ).

For an 11-day precompetency period, NRR under strict-homing hypotheses is significantly and positively correlated to regime 4 between days 1 and 5 after release with a maximum correlation coefficient of 0.5 (Figure 4c). Under no-homing hypotheses NRR is not 
355

356

357

358

359

360

361

362

significantly correlated to regime 4 , but correlation coefficients are generally positive (Figure 4c). For a 21-day precompetency period and under both homing hypotheses, NRR is significantly and positively correlated with regime 4 between days 4 and 5 after release with maximum correlation coefficients of 0.5 (Figure $4 d$ ).

Cross-correlations with regimes 2 and 3 are not significant.

\subsection{Settlement maps}

For an 11-day precompetency period, the average settlement map over the 1320 hatching events covering austral summer has non-zero settlement in nearly every suitable habitat, north and south of the natal reef (Figures 5a and 5b). Nevertheless, settlement is inhomogeneous over space, decreasing rapidly with distance from the natal reef and reaching very low values in the north and the south of the SWL (Figure 5a). The mean dispersal distance is $24.0 \mathrm{~km}$ (34.0 $\mathrm{km}$ for a 21 day precompetency period) and the center of mass is located slightly north of the natal reef.

When hatching is followed by a precompetency period dominated at $75 \%$ by weather regime 1, the vast majority of larvae settled north of the natal reef (Figure 6a). By contrast, when the precompetency period is dominated at $75 \%$ by regime 4 , larvae settle almost everywhere in the lagoon (Figure 6b). Settlement maps are very similar for a 21-day precompetency period (Appendix B, Figure B.1).

\subsection{Sensitivity to release depth}

At both spatial scales (natal reef and natal lagoon) and under both hypotheses (strict and no homing), time series of retention corresponding to different depth of release are positively correlated. For instance, NLR of larvae released in the upper layer (between 0 and $4 \mathrm{~m}$ depth) and NLR of larvae released in the bottom layer (between 16 and 20m depth) are correlated 
378 with a Spear-R of 0.4. The extremely high variability in simulated larval retention is equally

379 true for all release depth levels. Nevertheless time series show different magnitude depending

380 on the depth of release. Larvae released in upper layers had significantly less chance to settle

381 than larvae released in bottom layers (Figure 7). For example, NRR under the strict-homing

382 hypothesis averaged 8.1\% ( \pm 0.4 Standard Error) when larvae were released between 16 and

$38320 \mathrm{~m}$ depth, but only $4.8 \%$ ( \pm 0.2 Standard Error) when they were released between 0 and $4 \mathrm{~m}$

384 depth. These two values are significantly different (Student test p.value < 0.05). 


\section{Discussion}

387

388

389

390

391

392

393

394

395

396

397

398

399

400

401

402

403

404

405

406

407

408

409

410

Results from our larval dispersal modelling study show that larval retention is highly

temporally variable over a reproductive season in the South-West Lagoon of New Caledonia (SWL) at both lagoon and natal reef scales (Figure 2). Occasionally, we obtained much larger larval retention rates than suggested by short average water residence timescales reported by previous hydrodynamic studies in the SWL (Jouon et al. 2006, Ouillon et al. 2010, see introduction). These modelling studies assumed periodic tides and constant, uniform winds over the SWL corresponding to strong trade winds (SE, $8 \mathrm{~m} \mathrm{~s}^{-1}$ ), the most frequent and longlasting wind regime on New Caledonia (similar to Lefèvre et al.'s (2010) weather regime 1). Using realistic wind forcing, our results indicate that during periods of weaker (regime 4) winds, larvae can stay within the SWL for their entire precompetency period.

Correspondingly, larval retention rates during these periods can be as high as $100 \%$ for natal lagoon retention (NLR), and 43\%/23\% for natal reef retention (NRR) with / without homing respectively, for a precompetency period of 11 days. High retention rates occurred occasionally even for larvae released in the upper part of the water column and/or having a longer precompetency period, although average retention levels were smaller than for larvae released at greater depth (Figure 7) and/or having a shorter precompetency period (Figure 2). Homing behavior significantly increased retention at the reef scale (Figure 2), but it is not strictly necessary and all model configurations and simulations had at least some time periods with high levels of local retention.

High retention rates do not imply that populations are "closed" at the scale of individual reefs. In our study, NRR and NLR are highly positively correlated (Spear-R 0.63 and 0.82 , for NLR and NRR when no homing and strict homing, respectively), and non-zero settlement occurs over a large part of the SWL (Figure 5b). Nevertheless, settlement rates are low far from the natal reef (Figure 5a), suggesting that while there is non-zero exchange of genetic material 
411

412

413

414

over the entire SWL, population dynamics is dominated by processes occurring at smaller spatial scales. For example, protected areas of order 10's of $\mathrm{km}$ in size should have significant local retention of larvae and therefore a non-negligible chance of achieving self-persistence (Burgess et al. in press).

Natal reef retention (NRR) is generally called "local retention" (Botsford et al. 2009), i.e., the ratio of the number of larvae that settled back to their natal population to the total number of larvae released there. Local retention is clearly an important variable to consider in population dynamics studies. Indeed, an isolated population can persist if each individual produces enough offspring to replace itself in the next generation (Botsford et al. 2009, Burgess et al. in press) and this number increases with local retention. However, local retention is in practice difficult to measure as the reproductive output (number of larvae released) of a particular population must be assessed. This problem can be partially avoided by measuring local retention as defined by Hogan et al. (2012), i.e. the ratio of the number of larvae that settled back to their natal population to the total number of larvae released there that settled anywhere. This variable has been estimated in the field by Hogan et al. (2012) for a damselfish in the Caribbean, a species with life history traits very similar to ours. They found a mean value of $21 \%$ ( $\pm 12 \%$ Std. Dev.) on the 7 sites sampled over a 3-years study period. Hogan et al.'s (2012) definition of local retention corresponds exactly to NRR divided by NLR in our study. Values of NRR / NLR we obtain in our simulations are $2.0 \%( \pm 2.8 \mathrm{Std}$. Dev.) for a precompetency period of 11 days and $0.8 \%$ ( \pm 1.0 Std. Dev.) for a precompetency period of 21 days, i.e., respectively ten and twenty times smaller than the values assessed by Hogan et al. (2012). These differences are potentially due to differences in the sizes of natal vs. all settlement reefs. In our case, the natal reef represents only $0.01 \%$ of all settlement reefs in the SWL (Figure 1), whereas if the 7 sites considered by Hogan et al. (2012) have similar sizes, each site represents $\sim 1 / 7=14 \%$ of the total habitat considered. In both our study and 
Hogan et al.'s (2012), the fraction of larvae retained locally is superior to the fraction of habitat that the focal site represents, indicating that local retention is superior to what would be expected for a uniformly mixed larval pool, despite numerical retention rates being quite different between the two studies. This highlights the importance of taking habitat area into account when assessing local retention rates.

In order to understand the extremely high variability in simulated retention at both lagoon and reef scales, we calculated cross-correlations of retention time series with wind and weather regime time series. We found significant negative cross-correlations between all simulated retention time series and along-shore winds (approximately winds from the south-east) during the precompetency period (Figure 3), except for NRR under the no-homing hypotheses with an 11-day precompetency period. These results show that larval retention variability in the SWL is partly explained by wind forcing. Strong along-shore winds represent unfavorable conditions for larval retention in the SWL because resulting ocean circulation flushes larvae out of the lagoon before they have time to settle (Jouon et al. 2006, Ouillon et al. 2010). This overall pattern is reflected in the relationship between settlement and the wind regimes identified in Lefèvre et al. (2010). The strong SE trade wind regime (regime 1) is unfavorable to larval retention during the larval precompetency period (Figures $4 \mathrm{a}$ and 4b, Figure $6 \mathrm{a}$ ). By contrast, the subtropical regime (regime 4) is positively correlated to retention values during the first days of pelagic larval life for both precompetency period lengths studied (Figures $4 \mathrm{c}$ and $4 d$, Figure $6 \mathrm{~b}$ ). This regime is characterized by weaker SE winds with more variable direction than regime 1, including the majority of cross-shelf winds observed during our study period. Both these features reduce mean wind forcing and increase retention. Surprisingly, regime 1 had a slight but significant favorable effect on natal reef retention if occurring during the competency period (at a lag of approximately three weeks whatever the precompetency stage duration, Figures $4 \mathrm{a}$ and $4 \mathrm{~b}$ ). This suggests that optimal settlement conditions result 
461

462

463

464

465

466

467

468

469

470

471

472

473

474

475

476

477

478

479

480

481

482

483

484

485

from a combination of weak, regime-4 winds during the early part of the precompetency

period, followed by strong, regime- 1 winds close to the time of settlement (e.g. January $15^{\text {th }}$ $21^{\text {st }} 2004$; Figures $2 \mathrm{a}$ and 2e). When larvae disperse towards the south of the lagoon during the precompetency period as a result of regime- 4 winds, regime- 1 winds are needed for these to return to their natal reef (located in the center of the study area). This relationship breaks down when natal lagoon retention is considered because in this case larvae can settle in many different places within the SWL and therefore do not have to be transported back to the central natal site.

As shown in Lefèvre et al. (2010), the low-level circulation in New Caledonia varies significantly in connection with large scale forcing mechanisms, such as the El Niño/Southern Oscillation (ENSO) or the Madden Julian Oscillation (MJO). For example, Lefèvre et al. (2010) show that high regime 1 winds are more prevalent during El Niño events, the opposite being true during La Niña events. Since dynamics and residence time in shallow lagoons are tied to low-level winds, this implies that the large scale forcing may modulate larval retention in a similar way. Our results therefore suggest that El Niño (La Niña) years will lead to lower (higher) larval retention than average years. Given the strong correlation between retention rates and wind conditions, weather regimes and their connection with large scale oscillations (ENSO, MJO) may be a useful predictor of settlement success. To confirm the applicability of these proxies for settlement in the entire SWL, we compared retention time series from the focal reef with those from four other reefs located throughout the SWL, and found significant quantitative agreement in all but the most coastal reef (Appendix C), suggesting that weather regimes are likely a good predictor of settlement at intraseasonal and interannual scales over the majority of the SWL.

Real larval dispersal and settlement is considerably more complex than what is represented in our model, and we have consciously chosen not to explicitly represent a number of processes, 
486

487

488

489

490

491

492

493

494

495

496

497

498

499

such as larval mortality and vertical migration, because very little is known about them in general and particularly for our study species. Other modelling studies have demonstrated potentially significant effects of such processes on larval dispersal and connectivity (Paris et al. 2007, Brochier et al. 2008, Yannicelli et al. 2012). At this stage, our modelling work focused on investigating the effect of meteo-oceanography on larval retention and we believe that most of our qualitative conclusions on favorable and unfavorable wind conditions for retention remain largely unchanged if larval mortality or vertical migration were added in the model. Supporting this belief, including homing in our model did not lead to significant qualitative changes in our results (Figure 3, Figure 4), though absolute retention rates were affected (Figure 2).

\section{Acknowledgments}

This work was supported by the COMPO project (Connectivity Of Marine POpulations, www.compo.ird.fr) through a grant from the French National Research Agency (ANR), grant number 2010 JCJC 170101. 
500

501

502

503

504

505

506

507

508

509

510

511

512

513

514

515

516

517

518

519

520

521

\section{References}

Andréfouët, S., Torres-Pulliza, D., Dosdane, M., Kranenburg, C., Murch, B., Muller-Karger, F.E., Robinson, J.A., 2004. Atlas des récifs coralliens de Nouvelle Calédonie. IFRECOR, 26 p. +22 p.

Allen, G.R., 1991. Damselfishes of the World. Mergus Verlag, Melle, Germany: 1-271.

Almany, G.R., Berumen, M.L., Thorrold, S.R., Planes, S., Jones, G.P., 2007. Local

replenishment of coral reef fish populations in a marine reserve. Science 316 (5825): 742-744.

DOI: $10.1126 /$ science. 1140597

Bernhardt, J.R., Leslie, H.M., 2013. Resilience to climate change in coastal marine ecosystems. Marine Science 5: 371-392. DOI: 10.1146/annurev-marine-121211-172411

Berumen, M.L., Almany, G.R., Planes, S., Jones, G.P., Saenz-Agudelo, P., Thorrold, S.R., 2012. Persistence of self-recruitment and patterns of larval connectivity in a marine protected area network. Ecology and evolution 2 (2): 444-452. DOI: 10.1002/ece3.208

Black, K., Moran, P.P.J., 1991. Influence of hydrodynamics on the passive dispersal and initial recruitment of larvae of Acanthaster Planci (echinodermata, Asteroidea). Marine Ecology-Progress Series 69: 55-65.

Botsford, L.W., Paulsen, C.M., 2000. Assessing covariability among populations in the presence of intraseries correlation: Columbia River spring-summer chinook salmon (Oncorhynchus tshawytscha) stocks. Canadian Journal of Fisheries and Aquatic Sciences 57 (3): 616-627.

Botsford, L.W., White, J.W., Coffroth, M.A., Paris, C.B., Planes, S., Shearer, T.L., Thorrold, S.R., Jones, G.P., 2009. Connectivity and resilience of coral reef metapopulations in marine 
protected areas: matching empirical efforts to predictive needs. Coral Reefs 28: 327-337.

DOI: $10.1007 / \mathrm{s} 00338-009-0466-\mathrm{z}$

Brochier T., Lett, C., Tam, J., Fréon, P., Colas, F., Ayon, P., 2008. An individual-based model study of anchovy early life history in the northern Humboldt Current system. Progress in oceanography 79: 313-325. DOI:10.1016/j.pocean.2008.10.004

Burgess, S.C., Nickols, K.J., Griesemer, C.D., Barnett, L.A.K., Dedrick, A.G., Satterthwaite, E.V., Yamane, L., Morgan, S.G., White, J.W., Botsford, L.W. In press. Beyond connectivity: how empirical methods can quantify population persistence to improve marine protected area design. Ecological Applications. DOI: 10.1890/13-0710.1

Butler, M.J., Paris, C.B., Goldstein, J.S., Matsuda, H., Cowen, R.K., 2011. Behavior contrains the dispersal of long-lived spiny lobster larvae. Marine Ecologie Progress Series 422: 223237. DOI: $10.3354 / \mathrm{meps} 08878$

Chérubin, L.M., Nemeth, R.S., Idrisi, N., 2011. Flow and transport characteristics at an Epinephelus guttatus (red hind grouper) spawning aggregation site in St. Thomas (US Virgin Islands). Ecological Modelling 222: 3132-3148.

Christie, M.R., Tissot, B.N., Albins, M.A., Beets, J.P., Jia, Y., Ortiz, D.M., Thompson, S.E., Hixon, M.A., 2010. Larval connectivity in an effective network of Marine Protected Areas. PLOS ONE 5 (12): e15715. DOI: 10.1371/journal.pone.0015715

Coates, D., 1980. The discrimination of and reactions towards predatory and non-predatory species of fish by humbug damselfish, Dascyllus aruanus (Pisces, Pomacentridae). Zeitschrift für Tierpsychologie 52 (4): 347-354. DOI: 10.1111/j.1439-0310.1980.tb00722.x 
543

544

545

546

547

548

549

550

551

552

553

554

555

556

557

558

559

560

561

562

563

Cole, K., 2002. Gonad morphology, sexual development, and colony composition in the obligate coral-dwelling damselfish Dascyllus aruanus. Marine Biology 140 (1): 151-163.

DOI: $10.1007 / \mathrm{s} 002270100681$

Cowen, R.K., Gawarkiewicz, G.G., Pineda, J., Thorrold S.R., Werner, F.E., 2007. Population connectivity in marine systems: an overview. Oceanography 20 (3): 14-21.

Cowen, R.K., Lwiza, K.M.M., Sponaugle, S., Paris, C.B., Olson, D.B., 2000. Connectivity of marine populations: open or closed? Science 287 (5454): 857 -859. DOI:

$10.1126 /$ science. 287.5454 .857

Cowen, R.K., Paris, C.B., Srinivasan, A., 2006. Scaling of connectivity in marine populations. Science 311 (5760): 522 -527. DOI: 10.1126/science.1122039

Cowen, R.K., Sponaugle, S., 2009. Larval dispersal and marine population connectivity. Annual Review of Marine Science 1: 443-466. DOI: 10.1146/annurev.marine.010908.163757

Douillet, P., 1998. Tidal dynamics of the south-west lagoon of New Caledonia. Oceanologica Acta 21 (1): 69-79.

Douillet, P., Ouillon, S., Cordier, E., 2001. A numerical model for fine suspended sediment transport in the southwest lagoon of New Caledonia. Coral Reefs 20 (4): 361-372. DOI: 10.1007/s00338-001-0193-6

Egbert, G.D., Bennett, A.F., Foreman, M.G., 1994. TOPEX/POSEIDON tides estimated using a global inverse model, Journal of Geophysical Research 99: 24821-24852.

Faure, V., Pinazo, C., Torréton, J.P., Jacquet, S., 2010. Modelling the spatial and temporal variability of the SW lagoon of New Caledonia. I: A new biogeochemical model based on 
564

565

566

567

568

569

570

571

572

573

574

575

576

577

578

579

580

581

582

583

microbial loop recycling. Mar. Pollut. Bull. 61, 465-479 (New Caledonia tropical lagoons: an overview of multidisciplinary investigations).

Fisher, R., 2005. Swimming speeds of larval coral reef fishes: impacts on self-recruitment and dispersal. Marine Ecology Progress Series 285: 223-232. DOI: 10.3354/meps285223

Fuchs, R., Dupouy, C., Douillet, P., Dumas, F., Caillaud, M., Mangin, A., Pinazo, C., 2012. Modelling the impact of a La Niña event on a South West Pacific Lagoon. Marine Pollution Bulletin 64: 1596-1613.

Gerlach, G., Atema, J., Kingsford, M.J., Black, K.P., Miller-Sims, V., 2007. Smelling home can prevent dispersal of reef fish larvae. Proceedings of the National Academy of Sciences of the United States of America 104, 858-863.

Harrison, H.B., Williamson, D.H., Evans, R.D., Almany, G.R., Thorrold, S.R., Russ, G.R., Feldheim, K.A., van Herwerden, L., Planes, S., Srinivasan, M., Berumen, M.L., Jones, G.P., 2012. Larval export from marine reserves and the recruitment benefit for fish and fisheries.

Current Biology 22 (11): 1023-1028. DOI: 10.1016/j.cub.2012.04.008

Heyward, A.J., Negri, A.P., 2010. Plasticity of larval precompetency in response to temperature: observations on multiple broadcast spawning coral species. Coral Reefs 29: 631636. DOI: $10.1007 / \mathrm{s} 00338-009-0578-5$

Hogan, J.D., Thiessen, R.J., Sale, P.F., Heath, D.D., 2012. Local retention, dispersal and fluctuating connectivity among populations of a coral reef fish. Oecologia 168 (1): 61-71.

DOI: $10.1007 / \mathrm{s} 00442-011-2058-1$ 
584

585

586

587

588

589

590

591

592

593

594

595

596

597

598

599

600

601

602

603

604

605

Holbrook, S.J., Forrester G.E., Schmitt, R.J., 2000. Spatial patterns in abundance of a damselfish reflect availability of suitable habitat. Oecologia 122 (1): 109-120. DOI: 10.1007/PL00008826

Jackson, G.A., Strathmann, R.R., 1981. Larval mortality from offshore mixing as a link between precompetent and competent periods of development. The American Naturalist 118 (1): 16-26.

James, M.K, Armsworth, P.R., Mason, L.B., Bode, L., 2002. The structure of reef fish metapopulations: modelling larval dispersal and retention patterns. Proceedings of the Royal Society of London. Series B: Biological Sciences 269 (1505): 2079.

Jarrige, F., Radok, R., Krause, G., Rual, P., 1975. Courants dans le lagon de Nouméa (Nouvelle Calédonie). Unpublished manuscript ORSTOM Noumea.

Jones, G.P., Almany, G.R., Russ, G.R., Sale, P.F., Steneck, R.S., Oppen, M.J.H., Willis, B.L., 2009. Larval retention and connectivity among populations of corals and reef fishes: history, advances and challenges. Coral Reefs 28 (2): 307-325. DOI: 10.1007/s00338-009-0469-9

Jouon, A., Douillet, P., Ouillon, S., Fraunié, P., 2006. Calculations of hydrodynamic time parameters in a semi-opened coastal zone using a 3D hydrodynamic model. Continental Shelf Research 26 (12-13): 1395-1415. DOI: 10.1016/j.csr.2005.11.014

Juncker, M., Wantiez, L., Ponton, D., 2007. Flexibility in size and age at settlement of coral reef fish: spatial and temporal variations in Wallis Islands (South Central Pacific). Aquatic Living Resources 19 (4): 339-348. DOI: 10.1051/alr:2007004

Kool, J.T., Moilanen, A., Treml, E.A., 2013. Population connectivity: recent advances and new perspectives. Landscape Ecology 28 (2): 165-185. DOI: 10.1007/s10980-012-9819-z 
Lazure, P., Dumas, F., 2008. An external-internal mode coupling for a 3D hydrodynamical model for applications at regional scale (MARS). Advances in Water Resources 31 (2):

233-250. DOI: 10.1016/j.advwatres.2007.06.010

Lefèvre, J., Marchesiello, P., Jourdain, N.C., Menkes, C., Leroy, A., 2010. Weather regimes and orographic circulation around New Caledonia. Marine pollution bulletin 61 (7): 413-431.

Leis, J.M., 2010. Ontogeny of behaviour in larvae of marine demersal fishes. Ichthyological Research 57 (4): 325-342. DOI: 10.1007/s10228-010-0177-z

Leis, J.M., van Herwerden, L., Patterson, H.M., 2011. Estimating connectivity in marine fish populations: What works best? Oceanography and Marine Biology: An Annual Review 49: $193-234$.

Leis, J.M., Sweatman, H.P.A., Reader, S.E., 1996. What the pelagic stages of coral reef Fishes are doing out in blue water: daytime field observations of larval behavioural capabilities. Marine and Freshwater Research 47 (2): 401 -411. DOI: 10.1071/MF9960401

Lett, C., Verley, P., Mullon, C., Parada, C., Brochier, T., Penven, P., Blanke, B., 2008. A Lagrangian tool for modelling ichthyoplankton dynamics. Environmental Modelling and Software 23 (9): 1210-1214. DOI: 10.1016/j.envsoft.2008.02.005

Levin, L.A., 2006. Recent progress in understanding larval dispersal: new directions and digressions. Integrative and Comparative Biology 46 (3): 282. DOI: 10.1093/icb/icj024

Luettich Jr, R.A., Westerink, J.J., Scheffner, N.W., 1992. ADCIRC: An advanced threedimensional circulation model for shelves, coasts, and estuaries. Report 1 . Theory and Methodology of ADCIRC-2DDI and ADCIRC-3DL. Technical report. 143 p. 
627

628

629

630

631

632

633

634

635

636

637

638

639

640

641

642

643

644

645

646

647

648

Marchesiello, P., Lefèvre, J., Vega, A., Couvelard, X., Menkes, C., Ganachaud, A., 2010.

Coastal upwelling, circulation and heat balance around New Caledonia's barrier reef. Marine Pollution Bulletin 61: 432-448.

van der Meer, M.H., Hobbs, J.P.A., Jones, G.P., van Herwerden, L., 2012. Genetic

Connectivity among and self-replenishment within island populations of a restricted range

subtropical reef fish. PLOS ONE 7 (11): e49660. DOI: 10.1371/journal.pone.0049660

Miller, T.J., 2007. Contribution of individual-based coupled physical-biological models to understanding recruitment in marine fish populations. Marine Ecology Progress Series 347: 127-138. DOI: $10.3354 /$ meps06973

Mizushima, N., Nakashima, Y., Kuwamura, T., 2000. Semilunar spawning cycle of the humbug damselfish Dascyllus aruanus. Journal of Ethology 18 (2): 105-108. DOI: $10.1007 / \mathrm{s} 101640070008$

Mouristen, H., Atema, J., Kingsford, M.J., Gerlach, G., 2013. Sun compass orientation helps coral reef fish larvae return to their natal reef. PLOS ONE 8 (6): e66039.

Ouillon, S., Douillet, P., Lefebvre, J.P., Le Gendre, R., Jouon, A., Bonneton, P., Fernandez, J.M., Chevillon, C., Magand, O., Lefèvre, J., Le Hir, P., Laganier, R., Dumas, F., Marchesiello, P., Bel Madani, A., Andréfouët, S., Panché, J.Y., Fichez, R., 2010. Circulation and suspended sediment transport in a coral reef lagoon: The south-west lagoon of New Caledonia. Marine pollution bulletin 61: 269-296. DOI:10.1016/j.marpolbul.2010.06.023

Paris, C.B., Chérubin, L.M., Cowen, R.K., 2007. Surfing, spinning, or diving from reef to reef: effects on population connectivity. Marine Ecology Progress Series 347: 285-300. DOI: $10.3354 /$ meps06985 
649

650

651

652

653

654

655

656

657

658

659

660

661

662

663

664

665

666

667

668

669

Paris, C.B., Cowen, R.K., 2004. Direct evidence of a biophysical retention mechanism for coral reef fish larvae. Limnology and Oceanography 49 (6): 1964-1979.

Paris, C.B, Cowen, R.K., Claro, R., Lindeman, K.C., 2005. Larval transport pathways from Cuban snapper (Lutjanidae) spawning aggregations based on biophysical modeling. Marine Ecology Progress Series 296: 93-106.

Pesin, E., Blaize, S., Lacoste, D., 1995. Atlas climatique de la Nouvelle Calédonie, Météo France. Nouméa, New Caledonia. 104p.

Pillai, C.S.G., Mohan, M., Kunhikoya, K.K., 1985. Ecology and biology of the white-tailed Humbug Dascyllus aruanus (Pomacentriade, Pisces) from Minicoy Atoll. Journal of the Marine Biological Association of India 27 (1and2): 13-123.

Planes, S., Jones, G.P., Thorrold, S.R., 2009. Larval dispersal connects fish populations in a network of marine protected areas. Proceedings of the National Academy of Sciences 106: $5693-5697$.

Pyper, B.J., Peterman, R.M., 1998. Comparison of methods to account for autocorrelation in correlation analyses of fish data. Canadian Journal of Fisheries and Aquatic Sciences 55 (9): 2127-2140. DOI: 10.1139/f98-104

Radford, C.A., Stanley, J.A., Simpson, S.D., Jeffs, A.G., 2011. Juvenile coral reef fish use sound to locate habitats. Coral Reefs 30 (2): 295-305. DOI: 10.1007/s00338-010-0710-6

Saenz-Agudelo, P., Jones, G.P., Thorrold, S.R., Planes, S., 2012. Patterns and persistence of larval retention and connectivity in a marine fish metapopulation. Molecular Ecology 21 (19): 4695-4705. DOI: 10.1111/j.1365-294X.2012.05726.x 
670

671

672

673

674

675

676

677

678

679

680

681

682

683

684

685

686

687

688

689

690

691

Sale, P.F., 1972. Effect of cover on agonistic behavior of a reef fish: a possible spacing mechanism. Ecology 53 (4): 753-758. DOI: 10.2307/1934798

Sale, P.F., Cowen, R.K., Danilowicz, B.S., Jones, G.P., Kritzer, J.P., Lindeman, K.C., Planes, S., Polunin, N.V., Russ, G.R., Sadovy, Y.J., Steneck, R.S., 2005. Critical science gaps impede use of no-take fishery reserves. Trends in Ecology and Evolution 20 (2): 74-80.

Sale, P.F., Hanski, I., Kritzer, J.P., 2006. The merging of metapopulation theory and marine ecology: establishing the historical context. In: Kritzer, J.P., Sale, P.F (Eds), Marine metapopulations. Elsevier Academic Press, Burlington, USA, pp. 3-22.

Soeparno, Nakamura, Y., Shibuno, T., Yamaoka, K., 2012. Relationship Between Pelagic Larval duration and abundance of tropical fishes on temperate coasts of Japan. Journal of Fish Biology 80 (2): 346-357. DOI: 10.1111/j.1095-8649.2011.03175.x

Soria, G., Munguia-Vega, A., Marinone, S.G., Moreno-Baez, M., Martinez-Tovar, I., CudneyBueno, R., 2012. Marine Ecology Progress Series 463: 159-175. DOI: 10.3354/meps09866

Staaterman, E., Paris, C.B., Helgers, J., 2012. Orientation behavior in fish larvae: A missing piece to Hjort's critical period hypothesis. Journal of theoretical biology 304: 188-196. DOI: 10.1016/j.jtbi.2012.03.016

Sweatman, H.P.A., 1983. Influence of conspecifics on choice of settlement sites by larvae of two pomacentrid fishes (Dascyllus aruanus and D. reticulatus) on coral reefs. Marine Biology 75 (2-3): 225-229. DOI:10.1007/BF00406006

Thresher, R.E., Colin, P.L., Bell, L.J. 1989., Planktonic duration, distribution and population structure of Western and Central Pacific Damselfishes (Pomacentridae). Copeia (2): 420-434.

DOI: $10.2307 / 1445439$. 
692 Treml, E.A., Roberts, J.J., Chao, Y., Halpin, P.N., Possingham, H.P., Riginos, C., 2012.

693 Reproductive output and duration of the pelagic larval stage determine seascape-wide

694 connectivity of marine populations. Integrative and Comparative Biology 52 (4): 525-537.

695 DOI: $10.1093 / \mathrm{icb} / \mathrm{ics} 101$

696 Yannicelli, B., Castro, L., Parada, C., Schneider, W., Colas, F., Donoso, D., 2012.

697 Distribution of Pleuroncodes monodon larvae over the continental shelf of south-central

698 Chile: Field and modeling evidence for partial local retention and transport. Progress in 699 oceanography 92-95: 206-227.

700 


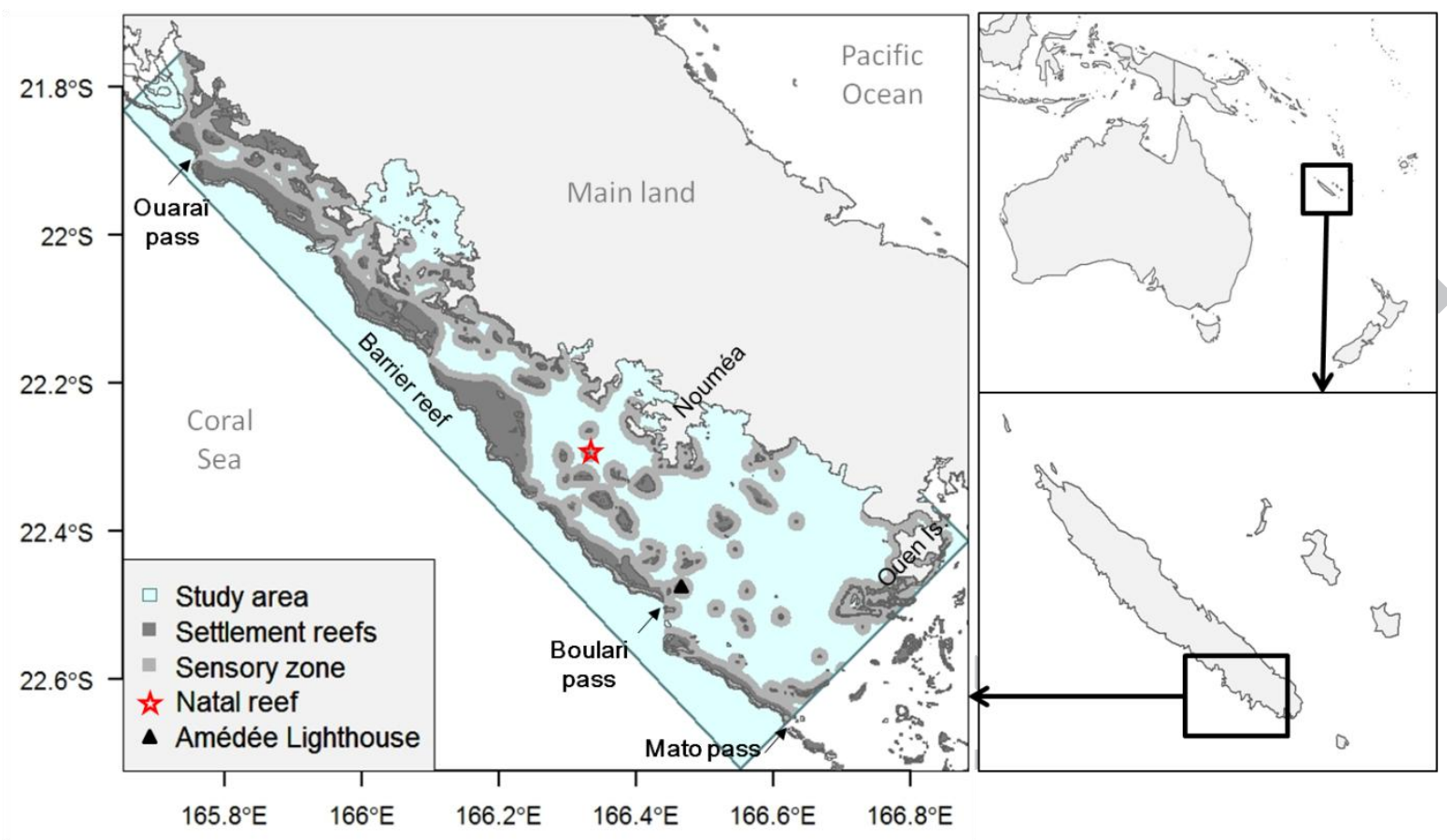

Figure 1: Study area: the South-West Lagoon of New Caledonia (SWL in light blue).

Settlement reefs (in dark grey) are buffered by a 1-km sensory zone (in light grey). 
Table 1: Description of the four weather regimes defined in Lefèvre et al. (2010). Statistics of wind speed and direction were computed from remote sensed surface winds for the period 1999-2008 (from Lefèvre et al. 2010).

\begin{tabular}{llccccc}
\hline \multirow{2}{*}{ Name } & \multirow{2}{*}{$\begin{array}{c}\text { \% of } \\
\text { occurrence }\end{array}$} & \multicolumn{2}{c}{ Wind speed $\left(\mathrm{m} \mathrm{s}^{-1}\right)$} & \multicolumn{2}{c}{ Wind direction ( $\left.{ }^{\circ} \mathrm{N}.\right)$} \\
\cline { 4 - 7 } & & & Mean & Std. Dev. & Mean & Std. Dev. \\
\hline Regime 1 & Strong SE Trade-wind & $30 \%$ & 8 & 2.2 & 122.5 & 21.6 \\
Regime 2 & Weak Easterly Circulation & $7.4 \%$ & 1.4 & 2.3 & 120.6 & 94.8 \\
Regime 3 & Tropical SE wind & $22.6 \%$ & 5.2 & 2.8 & 122.9 & 60.5 \\
Regime 4 & Subtropical SE wind & $27.3 \%$ & 5.2 & 2.2 & 118.9 & 45.6 \\
\hline
\end{tabular}




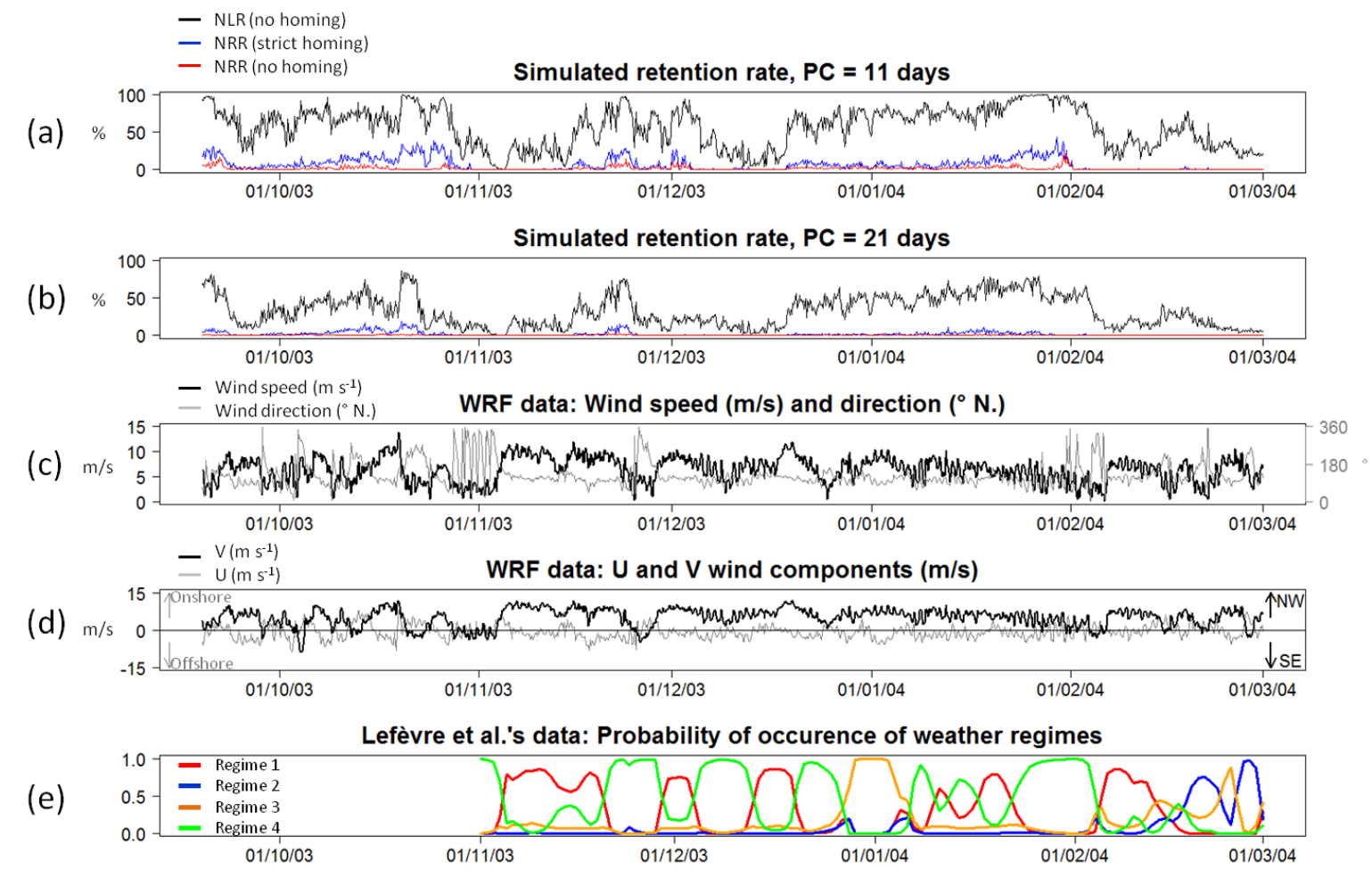

Figure 2: $(a, b)$ Simulated retention rate time series: natal lagoon retention (NLR) under the no-homing hypothesis (black), natal reef retention (NRR) under the no-homing hypothesis (red) and NRR under the strict-homing hypothesis (blue) for two values of precompetency period (PC): (a) $\mathrm{PC}=11$ days; (b) $\mathrm{PC}=21$ days. Each time series provides larval retention rate corresponding to 1320 hatching events from mid-September 2003 to early March 2004: retention rates are plotted for each corresponding release date. (c) WRF wind speed and direction; (d) WRF U and V wind components; (e) Probability of occurrence of weather regimes defined by Lefèvre et al. (2010) from early November 2003 to early March 2004. 

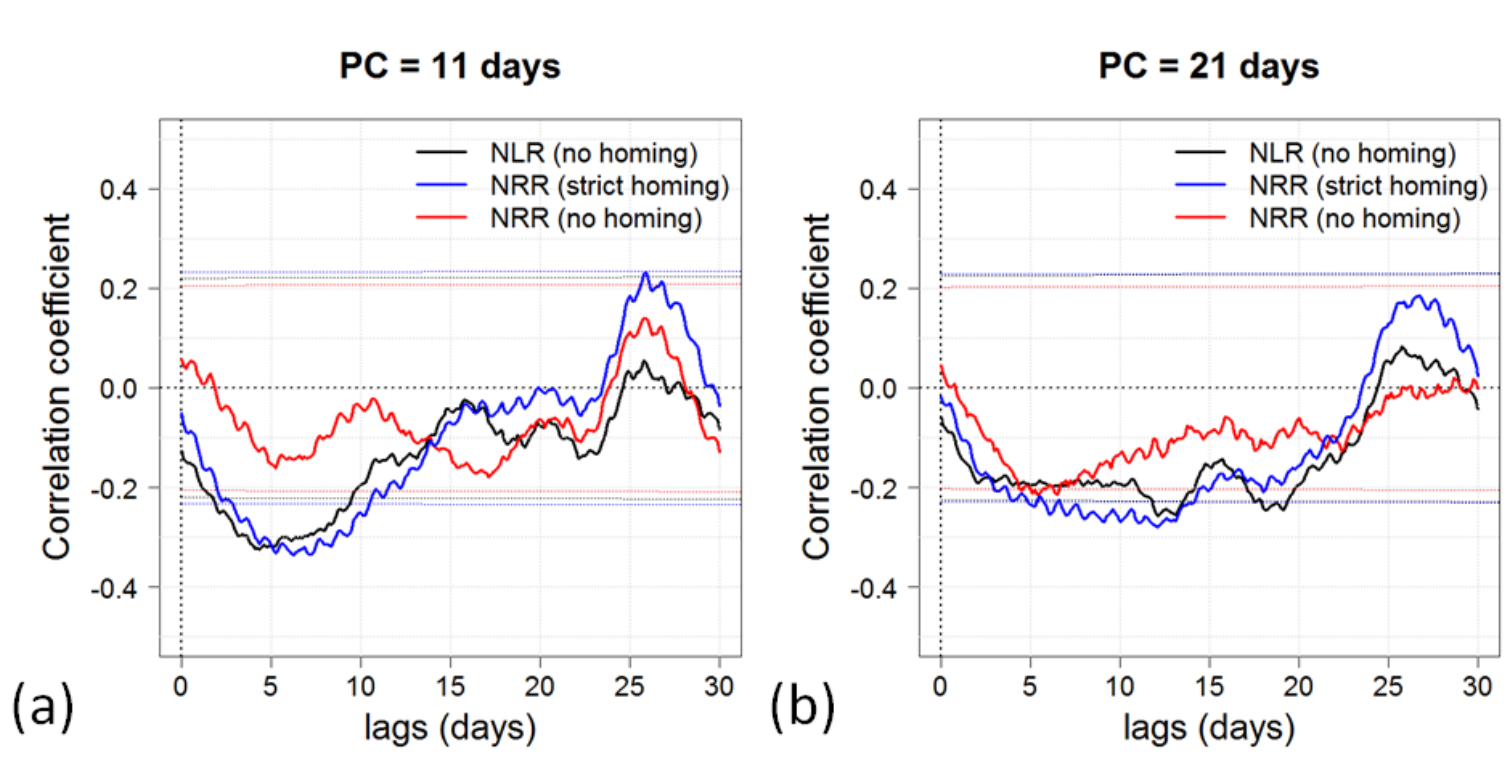

Figure 3: Cross-correlations between retention time series and along-shore wind component (V) derived from WRF model for two precompetency periods (PC) and under the hypothesis of strict and no homing. NLR: natal lagoon retention; NRR: natal reef retention. Dotted lines represent cross-correlation critical values with a 95\% level of confidence, adjusted to take into account temporal autocorrelation of time series. 


\section{Cross-correlation coefficients with regime 1}
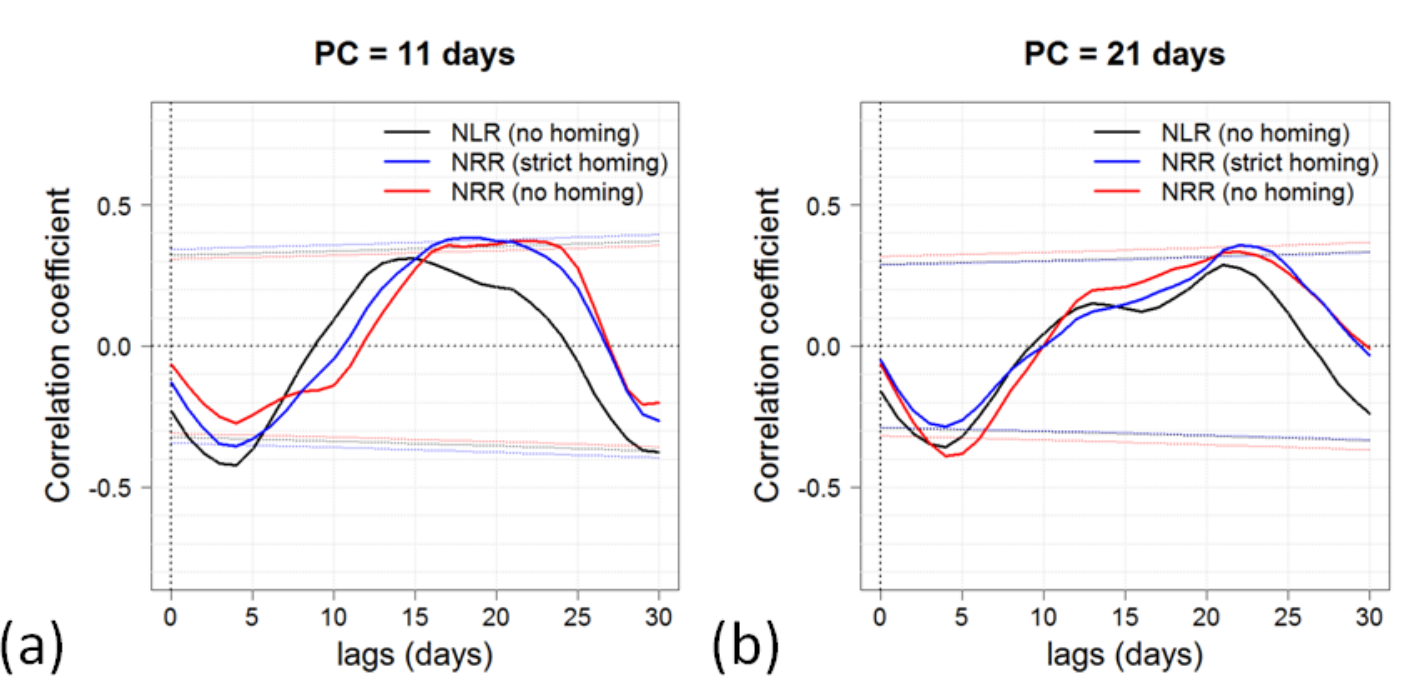

\section{Cross-correlation coefficients with regime 4}
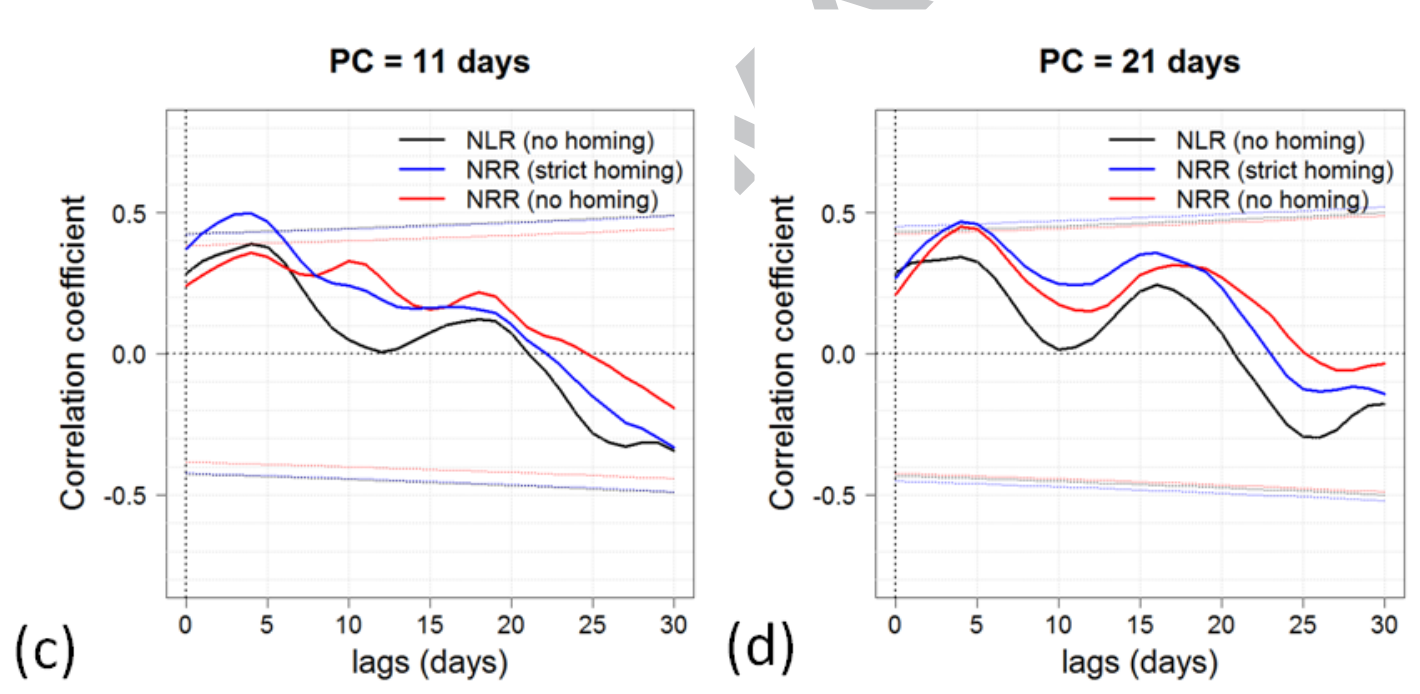

Figure 4: Cross-correlations between retention time series and weather regimes 1 and 4 for two precompetency periods (PC) and under the hypothesis of strict and no homing. NLR: natal lagoon retention; NRR: natal reef retention. Dotted lines represent cross-correlation critical values with a $95 \%$ level of confidence, adjusted to take into account temporal autocorrelation of time series. 
(a)

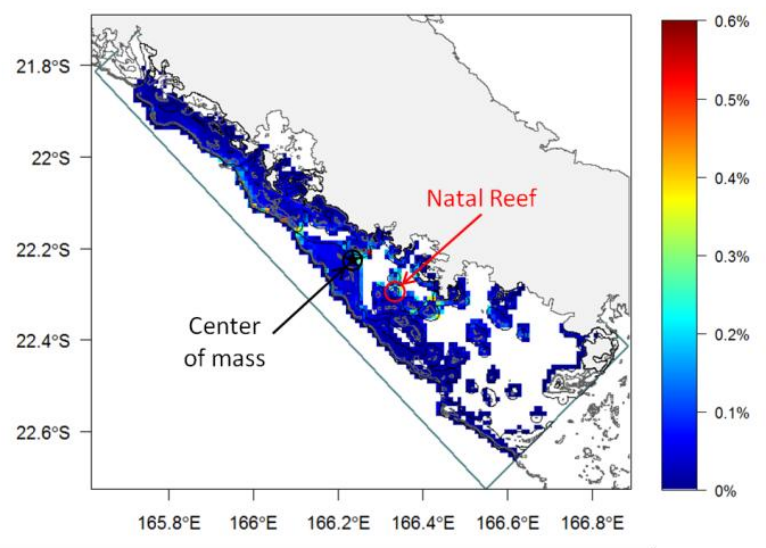

(b)

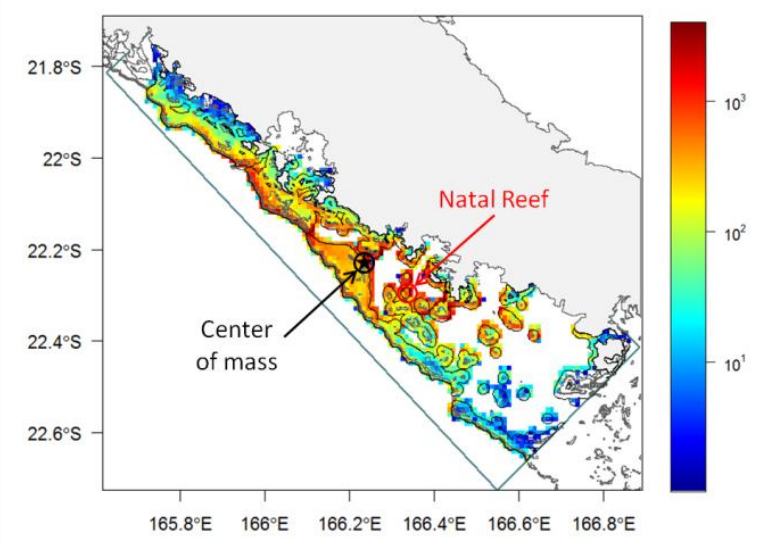

Figure 5: Maps of settlement using an 11-day precompetency period. For each simulation, the number of settlers was computed in square grid cells of $0.01^{\circ}$ in size. For each grid cell, the number of settlers was (a) averaged over the whole simulated period (1320 simulations) and presented as a percentage of the total number of particles released and (b) calculated on a logarithmic scale as $\log 10\left(N_{i}+1\right)$ where $N_{i}$ is the number of particles settling in grid cell $i$. 
(a) PC dominated by Regime 1

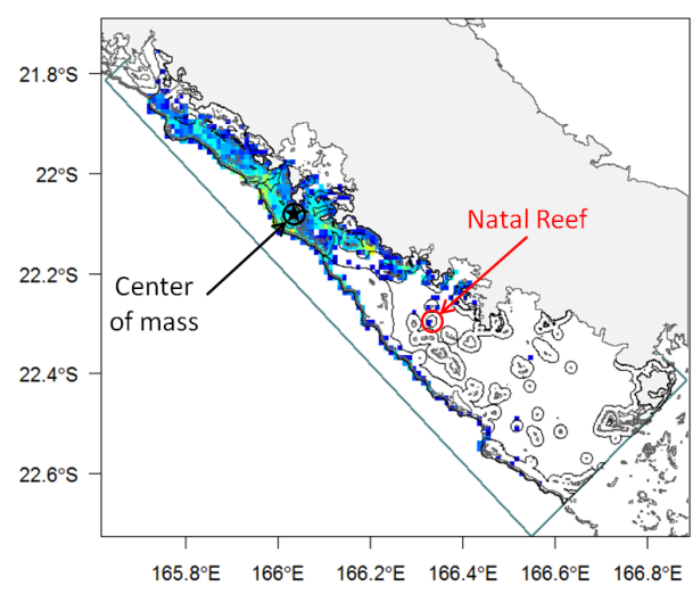

(b) PC dominated by Regime 4

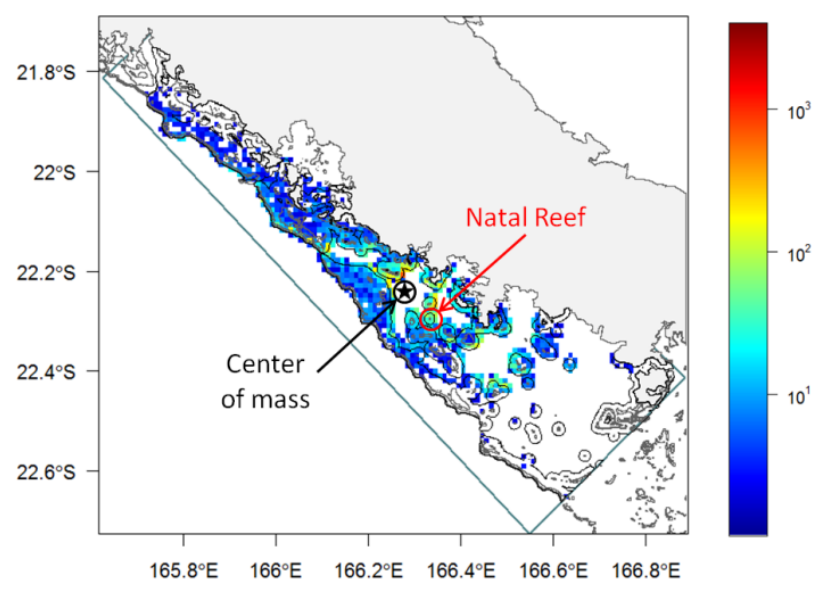

Figure 6: Maps of settlement using an 11-day precompetency period. The number of settlers was computed in square grid cells of $0.01^{\circ}$ in size for simulations corresponding to hatching events followed by (a) a precompetency period dominated at $75 \%$ by weather regime 1 (42 simulations) and (b) a precompetency period dominated at $75 \%$ by weather regime 4 (34 simulations). For each grid cell, the number of settlers was calculated on a logarithmic scale as $\log 10\left(N_{i}+1\right)$ where $N_{i}$ is the number of particles settling in grid cell $i$. 


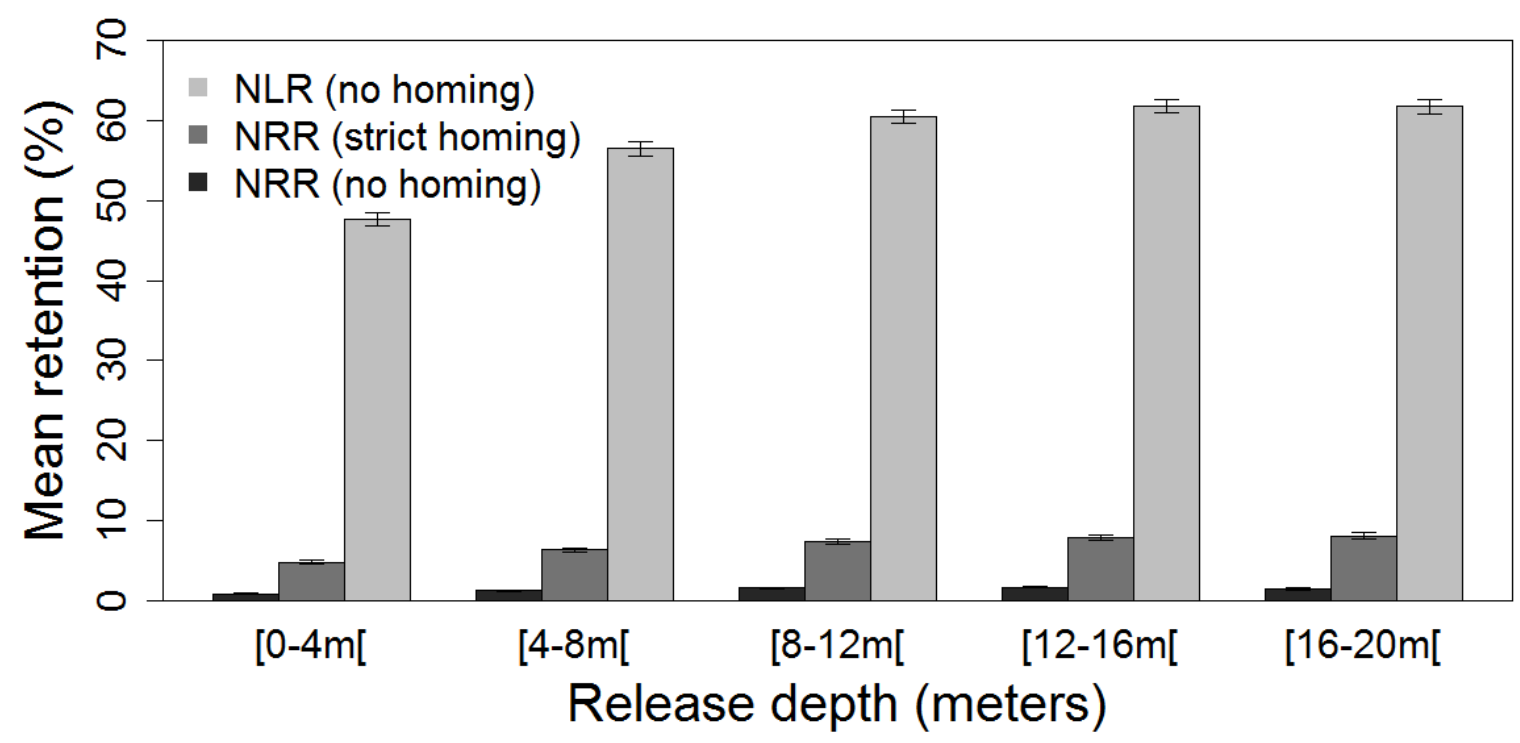

Figure 7: Mean retention over the austral summer 2003-2004 at natal reef scale (NRR) under no-homing and strict-homing hypotheses and at lagoon scale (NLR) under no-homing hypothesis for different release depths for an 11-day precompetency period. Error bars represent standard errors. 


\section{APPENDIX A}

WRF wind validation

Wind conditions predicted by the WRF model during austral summer 2003-2004 were compared to in situ data obtained from Amédée Lighthouse Météo-France weather station.

This station is located along the barrier reef on a patch of reef close to the Boulari pass approximately $20 \mathrm{~km}$ offshore in front of Nouméa (Figure 1) and is representative of marine weather conditions in the SWL (Lefèvre et al. 2010). The station provides hourly wind speed $\left(\mathrm{m} \mathrm{s}^{-1}\right)$ and direction $\left({ }^{\circ} \mathrm{N}\right)$ with an accuracy of $1 \mathrm{~m} \mathrm{~s}^{-1}$ for wind speed and $10^{\circ}$ for direction. The WRF predicted wind variables are extracted at the closest grid point to Amédée Lighthouse station and 6-hourly averages are computed for wind vector of both model and observations. Observations marked with low wind data (speed $<3 \mathrm{~m} \mathrm{~s}^{-1}$ ) are removed prior to the statistical computation of wind direction. Validation of predicted wind with observation was done through statistical performance measures including the root mean square error (RMSE) and Index of agreement (IOA) according to Lefèvre et al. (2010). The IOA is a measure of model skills in predicting variations about the observed mean; a value above 0.5 is considered to be good, 1 means a perfect match (see Lefèvre et al. (2010) for more details about this index).

Table A.1: Statistical comparison between WRF model predicted values and observations at Amédée Lighthouse weather station.

\begin{tabular}{llccccc}
\hline & \multirow{2}{*}{ Name } & \multirow{2}{*}{$\begin{array}{c}\text { \% of } \\
\text { occurrence }\end{array}$} & \multicolumn{2}{c}{ Wind speed $\left(\mathrm{m} \mathrm{s}^{-1}\right)$} & \multicolumn{2}{c}{ Wind direction ( ${ }^{\circ} \mathrm{N}$.) } \\
\cline { 4 - 7 } & & & Mean & Std. Dev. & Mean & Std. Dev. \\
\hline Regime 1 & Strong SE Trade-wind & $30 \%$ & 8 & 2.2 & 122.5 & 21.6 \\
& Weak Easterly & $7.4 \%$ & 1.4 & 2.3 & 120.6 & 94.8 \\
Regime 2 & Circulation & $22.6 \%$ & 5.2 & 2.8 & 122.9 & 60.5 \\
Regime 3 & Tropical SE wind & $27.3 \%$ & 5.2 & 2.2 & 118.9 & 45.6 \\
Regime 4 & Subtropical SE wind & & & & & \\
\hline
\end{tabular}




\section{APPENDIX B}

(a)

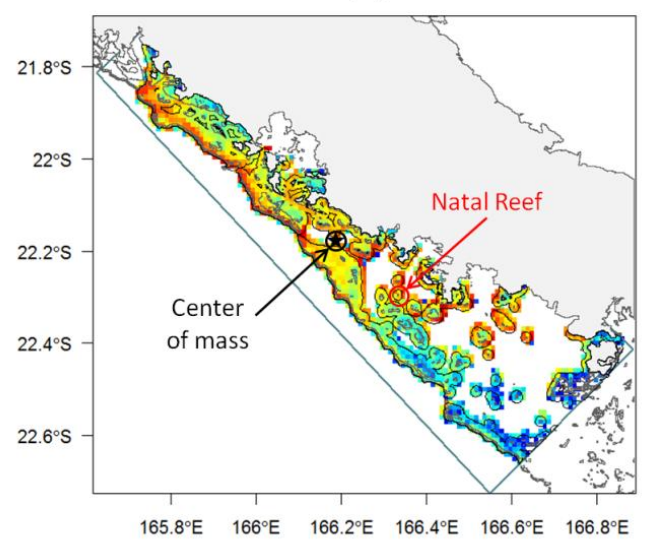

(b)

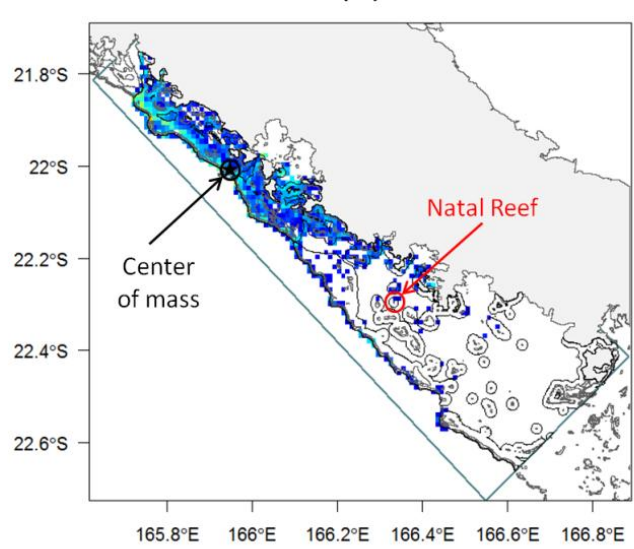

(c)

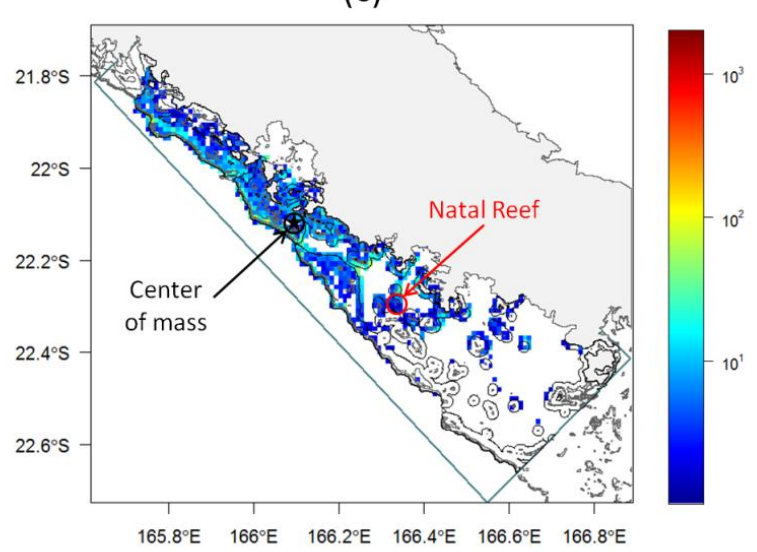

Figure B.1: Maps of settlement using a 21-day precompetency period. For each simulation, the number of settlers was computed in square grid cells of $0.01^{\circ}$ in size. For each grid cell, the number of settlers was calculated on a logarithmic scale as $\log 10\left(N_{i}+1\right)$ where $N_{i}$ is the number of particles settling in grid cell $i$ over (a) the whole simulated period (1320 simulations) and for simulations corresponding to hatching events followed by (b) a precompetency period dominated at $75 \%$ by weather regime 1 (42 simulations) and by (c) a precompetency period dominated at $75 \%$ by weather regime 4 (34 simulations). 


\section{APPENDIX C}

We based our study on larval releases from a patch reef located at the center of the SWL where water residence time is close to the average of 11 days (Ouillon et al. 2010). In order to evaluate the impact of this natal reef choice in the results we simulated larval retention for 4 other natal reefs. We chose a reef located $25 \mathrm{~km}$ further south of the focal reef (reef 2) and a reef $20 \mathrm{~km}$ further north (reef 4) in areas where water residence time is also close to the average of 11 days (Ouillon et al. 2010), and 2 others reefs located on the barrier reef (reef 3) and close to the coast (reef 1) where water residence times are around 5 and 20 days respectively (Ouillon et al. 2010) (Appendix C, Figure C.1). We simulated NRR under the strict-homing hypothesis and NLR under the no-homing hypothesis for an 11-days precompetency period and we calculated Spearman rank-order correlation coefficient (SpearR) between the retention time series for the focal reef and the four other reefs (Appendix C, Table C.1). Average retention values ranged from $1.6 \%( \pm 2.1 \%$ Std. Dev., reef 3$)$ to $7.3 \%( \pm$ $7.8 \%$ Std. Dev., reef 4$)$ and from $48.9 \%$ ( $\pm 20.7 \%$ Std. Dev., reef 3$)$ to $73.6 \%( \pm 18.1 \%$ Std. Dev., reef 2) for NRR and NLR, respectively. For NRR we found significant positive correlations of varying intensities between focal reef and the reefs 1, 2, 3, and 4 (Spear-R 0.1, $0.2,0.5$ and 0.7 respectively). For the NLR we found significant positive correlations between focal reef and reef 3 and 4 (Spear-R 0.3 and 0.7), a not significant positive correlation between focal reef and reef 2 (Spear-R 0.1), but a significant negative correlation between focal reef and reef 1 (Spear-R -0.2). We relate the singularity of reef 1 to its position in a coastal area where gyres are generated by trade winds (Douillet et al. 2001). However in these gyres areas (North of Ouen Island in the southeast part of the SWL and in bays, Appendix C, Figure C.1) the habitat of our study species is scarce. For these reasons we strongly believe that the conclusions of our study based on the focal reef remain meaningful for a large part of the SWL where our study species is present (parch reefs and barrier reefs). 


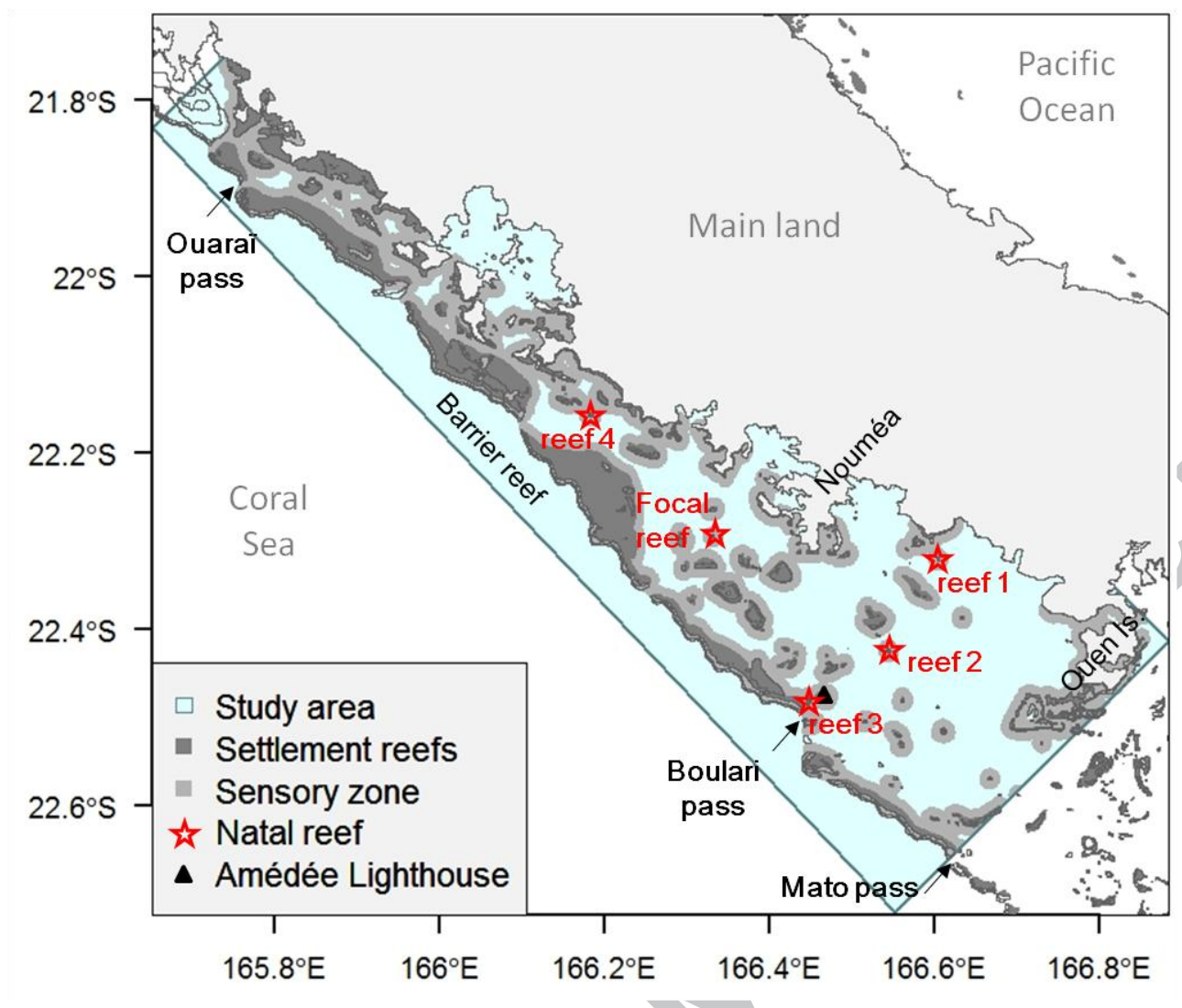

Figure C.1: Location of the focal reef and the four reefs used to evaluate the impact of the focal reef choice on the results. 


\section{Highlights}

1. We develop a biophysical, individual-based model for larvae of Dascyllus aruanus.

2. Larval retention at natal reef and lagoon scales is highly variable over time.

3. Large-scale weather regimes are good proxies for retention rates.

4. Mean dispersal distances are of order $25-35 \mathrm{~km}$. 
Keywords: Biophysical model; larval dispersal; wind-driven transport; Dascyllus aruanus; precompetency; homing; New Caledonia

Abstract: In the present work, a biophysical dispersal model is used to understand the role of the physical environment in determining reef fish larval dispersal patterns in the South-West Lagoon of New Caledonia. We focus on a reef fish species, the humbug damselfish Dascyllus aruanus, to investigate seasonal variability of simulated larval retention at the scale of a reef patch and at the scale of the lagoon, and to explore links between larval retention and wind variability. The model shows that retention exhibits considerable temporal variability and periodically reaches values much larger than anticipated. Non-zero larval settlement occurs over a large part of the lagoon. Nevertheless, settlement values decrease quickly away from the natal reef and mean dispersal distances are of order 25-35 km. Cross-correlation analyses indicate that weather conditions characterized by strong south east trade winds lead to low retention rates at both local (reef) and regional (lagoon) scales. By contrast, subtropical weather conditions characterized by weak winds result in high retention rates. These results suggest that large-scale weather regimes can be used as proxies for larval retention of the humbug damselfish in the South-West Lagoon of New Caledonia. Nevertheless, relatively small mean dispersal distances suggest that meta-population dynamics occur on relatively small spatial scales. 